\title{
Strategy of Universal War:Padri War in The Face of the Netherlands inMinangkabau in 1803-1838
}

\author{
Abdur Rahim, Sutrimo Sumarlan, Arief Rachman \\ University of Defense of the Republic of Indonesia, Bogor, West Java, Indonesia
}

\begin{abstract}
This article discusses the Strategy of The Padri War in the face of the Netherlands in Minangkabau, which took place in the early 17th century, precisely from 1803 to 1838 . The historical background of the Padri War began with religious and customary issues, but the final period of the Padri war on the own consciousness of the Padri and the Indigenous people turned into jointly against the Netherlands. This war became a place of resistance of the Minangkabau people against Netherlands invaders led by several prominent figures known as The Tiger Nan Salapan. The last period of the Padri war in 1830-1837, which was a war between the coalition of indigenous peoples and padri against the Netherlands, received its own assessment from the Netherlands. The Netherlands recognized that the Padri war was a difficult enough war for the Netherlands to win, and it became a record for the Netherlands that the Padri war was the longest war in Netherlands history. Guerrilla warfare strategy supported by the full force of indigenous people and Padri in the war overwhelmed the Netherlands forces, resulting in many casualties. After 35 years of Netherlands fighting against Padri forces, then Minangkabau can be controlled by the Netherlands, Tuanku Imam Bonjol as warlord Padri captured then on January 19, 1839 exiled to Ambon, then in 1841 transferred to Manado until his death on November 6, 1864.
\end{abstract}

Keywords: Strategy of Universal War, Padri War, Minangkabau

\section{INTRODUCTION}

$\mathrm{I}$ ndonesia was generally colonized by European nations within hundreds of years, they came to bring the spirit of imperialism by carrying out the mission of 3G (Gold, Glory and Gospel). Weigert and W. Hans in their book Principles of Political Geography (1957) explained that 3G (Gold, Glory and gospel) was a form of the Treaty of Tordesillas by the Portuguese and Spanish that contained a fatwa from Pope Alexander VI of the Vatican about the mission of the two Catholic kingdoms at that time [1]. This mission is carried out by Europeans when colonizing in Indonesia, namely 3G: Gold (acquiring wealth), Glory (glory) and Gospel (carrying the mission of spreading religion).

Based on the historical records of several European nations (Portuguese, British and Netherlands), the Netherlands were the longest colonized in Indonesia. The beginning of the Netherlands entry into Indonesia was marked by the arrival of Cornelis de Houtman in 1596 until the Netherlands established a trade union known as voc in 1602 to 1799 [2]. The Netherlands began to enter Indonesian territory to trade spices, but over time, the Netherlands began to implement imperialism and colonialism to facilitate the gain of natural wealth.

In the $1800 \mathrm{~s}$ in general, Indonesia was controlled by the Netherlands, his arrival politically was to want to control Indonesia both from his government and in the field of trade [3], one of which was the Minangkabau region. When the Netherlands came back to Minangkabau in the 18th century, in Minangkabau there was a conflict / civil war between the Indigenous people and the Padri. The arrival of the Netherlands met resistance from the Padri, so that there was a battle known as the Padri war. At that time the Priests controlled three strategic areas (luhak) in Minangkabau namely Tanah Datar, Luhak Agam and Lima Puluh Kota, as the beginning of the Minangkabau region, and the central center of Pagaruyung Kingdom was in the area of Tanah Datar. Based on tambo (history / saga) the origin of the word Minangkabau comes from the word "Manangkabau" which is the Minangkabau community won in a buffalo race with a large group that wants to control Minangkabau, so that since then the local community calls its territory as Minangkabau [4].

The Padri War was the longest in the history of the war against the Netherlands, from 1803 to 1838 . Initially this war was a war caused by opposition in the issue of religious understanding in everyday life, finally the Padri and indigenous people agreed to join the one great power to fight against the Netherlands. The Netherlands recognized that the strength of the Padri army was very tough and difficult to defeat, Captain Hendriks, a Netherlands army officer who wrote in his diary about the war in Minangkabau (1881). According to Captain Hendriks that the Minangkabau's strength was extraordinary, even in the most difficult circumstances, the Minangs could still show their extraordinary courage in battle. For example, when the Netherlands attacked the Lintau area, despite the strength of the Padri forces in small numbers, militancy was still high in the war. Padri's troops were accustomed and trained in the battlefield, even his combat spirit until the last drop of blood remained spirited to achieve victory in the war [5].

The authors of this study wanted to reveal about how padri's war strategy in the battle against the Netherlands in Minangkabau and what encouraged the unity of the Indigenous and Padri from the united civil war against the Netherlands. To the author's knowledge there has been no research related to the Strategy of Universal War: The Padri 
War in The Face of the Netherlands in Minangkabau in 18031838. Most of the literature obtained, both in the form of journals and books that the author got a lot discussed the topic of the da'wah movement of the Padri in Minangkabau. Little discusses the historical series of the struggle of the Padri in the war against the Netherlands in Minangkabau. Therefore, with the absence of previous research, it can be said that the author's research can be said there is novelty in a study.

The benefits of this research are as reference materials and enrich the study of universal war strategies based on the trajectory of the history of war that occurred in several regions in Indonesia.

\section{RESEARCH METHOD}

Research methods that the author uses in journal writing is to use the method of literature study (library research) that the author gets from various sources of literature, both through books, literature, websites, journal articles, magazines, research results and so on. The approach method in this study is a qualitative approach, which is used to know or describe the reality of the events studied making it easier for researchers to obtain objective data [6].

\section{Padri War Background}

Based on the historical background that there are two factors that cause the padri war to begin in 1803, first when three people from Minangkabau who had just returned from Makkah finished performing hajj in the holy land, known as Haji Miskin, Haji Sumanik, and Haji Piobang. Where these three pilgrims initially wanted to intend to straighten out the sharia teachings of Islam in Minangkabau which at that time had not been fully practiced in their daily lives [7]. The three of them saw various impossibility and maximal activities often occurred such as gambling, cockfighting, deprivation and murder as if it had become a spectacle and a common thing for the community at that time. This movement also attracted the attention of a cleric named Tuanku Nan Renceh to participate in supporting the holy intentions of the three pilgrims who had just returned from Makkah by inviting other scholars to participate and known as the group "Harimau Nan Salapan" [8]. The term Tiger Nan Salapan is the designation of the leader in the Padri movement of eight people consisting of Tuanku Nan Renceh, Tuanku Pasaman, Tuanku Rao, Tuanku Tambusai, Tuanku Lintau, Tuanku Mansiangan, Tuanku Berbakat Sikek and Tuanku Barumun [9].

Another factor that drove the birth of the Padri movement is the political conflict about the power structure and government, where the scholars only act as spiritual educators in the community. Though the position and function of scholars in the traditional order of minangkabau nature is included elements of leadership whose position is the same as Ninik Mamak (Chieftain), Cerdik Pandai (element of government) known as "tali tigo sapilin or tungku tigo sajarangan" [10]. These three elements of leadership are what govern the order of daily life of the Minangkabau People, so that the three of them must not be together in leading and making a decision in people's lives.

Seeing the conditions that existed in the minangkabau indigenous people at that time, the teachings of Islam were not carried out in accordance with the rules of the Qur'an and Hadith, then the Padri used force to be able to change habits as a form of amar ma'ruf nahi mungkar. As a result of the inevitable civil war, the Padri attacked the kingdom of Pagaruyung palace and caused Sultan Arifin Muningsyah to flee the palace. So that at that time the Padri began to be famous for its characteristics, namely white-and-white and turbaned clothes that opposed the sale and use of opium in the Minangkabau region [11]. The term Padri means clergy assigned to maintain the spirituality of army members [12].

Based on the background of differences in principles regarding the teachings of Islam between indigenous peoples and Padri, there was a civil war in the Minangkabau region known as the Padri war, but eventually turned into a unified war against the Netherlands. Padri War is the longest war in the Minangkabau region, namely in 1803-1838 which resulted in many casualties both on the part of the Indigenous people and from the Padri themselves.

\section{Period of the Padri War}

Padri's long war span of 35 years from 1803-1838 can be divided into two phases. The first phase of 1803-1821 (War between the Padri and the Indigenous People), which in the first phase was a very sad civil war because of the many casualties from both sides. The cause of the war is a difference in principles in understanding the issue of Islamic teachings led by three Minangkabau people who just returned to perform hajj in Mecca. Padri War began with the emergence of the opposition of a group of scholars dubbed the Padri against the Indigenous people because of the bad habits that are rife by the community in the Pagaruyung Kingdom and surrounding areas. It turns out that this reform movement is opposed by indigenous leaders consisting of indigenous leaders and nobles. Finally the Padri chose the settlement in force so that there was a religious civil war under the name padri war (1803-1821).

During this war, the Padri gained victory in almost all of the Minangkabau region, so that since 1805 the position of the Indigenous people was increasingly pushed because the Minangkabau royal family was killed. Finally the indigenous people and the surviving royal family asked for help to the British (under Raffles who was still in power in West Sumatra). When the British ceded West Sumatra to the Netherlands, it was in accordance with an agreement between The United Kingdom and the Netherlands in London in 1814. The result of his decision that Britain should leave Minangkabau and his role was replaced by the Netherlands [13].

Since then the indigenous people gained strong strength from the Netherlands to block the onslaught of the Padri. In fact, the 
Netherlands move was not solely aimed at helping the indigenous people, but more aimed at instilling its power in minangkabau. So as evidence on February 18, 1821 the Netherlands occupied Simawang Fort which is a former English Fort, through the golden road koto Piliang, Si Pinang, to Tambangan and Batipuh [14], and since then the beginning of the padri war against the real Netherlands [15]. Based on this description it can be seen that the role of the Indigenous people as the main enemy (opponent of conflict) of the Padri when it was replaced by the Netherlands, so the challenge of the opponent is getting tougher for the Padri.

The second phase in 1821-1838 (War between the Padri against the Netherlands), marked by the agreement between the indigenous peoples and the Netherlands as a form of cooperation against the Priests on February 10, 1821[16]. This is a sign of the start of the participation of third parties, namely the Netherlands in the Padri war, as the beginning of the influence of Netherlands power in the Minangkabau highlands (Padangsche Bovenlanden), which previously only controlled the west coast of Minangkabau (Padangsche Benedenlanden) [17]. the second phase of the Padri War was divided into three periods of war.

The first period (1821-1825) was a total war with the start of resistance throughout the Minangkabau region against the Netherlands. The Padri pounded the Netherlands outposts in Semawang, Sulit Air, and other places, so many victims fell from both sides. So the Netherlands changed the tactics of the war by establishing a fortress as a defense at Batusangkar (Fort Van der Capellen) and Fort de Kock fort in Bukittinggi. But Netherlands defenses with existing fortifications did not guarantee victory in the war, even suffered total defeat everywhere, including in Marapalam and in The Sulit Air. Finally the Netherlands changed their strategy again by means of diplomacy, namely persuading the Padri to make peace on January 22, 1824 in Masang and in the area VI Koto. As for the content of the peace is that both sides will obey their respective territorial boundaries, this negotiation actually only benefits the Netherlands side to delay the time to strengthen its power for war again. After successfully strengthening its defense, the Netherlands did not want to obey the agreement and two months later the Netherlands attacked the Padri again.

The second period (1825-1830) was marked by the easing of fighting, the Padri needed to assemble a force, while the Netherlands were in difficult circumstances, because they only focused their attention and sent troops to strengthen the resistance in the Diponegoro war in Central Java. Thus there was a truce marked by the Masang agreement, which stipulated that the two sides would not attack each other, protect each other people who were returning from displacement and who were on their way and trading, the Netherlands would recognize power in Lintau, Fifty Cities, Telawas and Agam [18]. This situation was used by the Padri led by Tuanku Imam Bonjol to embrace the Indigenous people to jointly fight against the Netherlands, so that in 1837 a common consensus was born that sought to uphold the teachings of Islam in the Minangkabau region.

The joint consensus between the Indigenous people and the Padri is called the Sati Bukik Marapalam Oath Agreement, namely The Basandi Syarak Custom, Syarak Basandi Kitabullah. This agreement changed the philosophy of life formula of the Minangkabau people which originally read Adat basandi Syarak, Syarak basandi Adat to Adat Basandi Syarak, Syarak Basandi Kitabullah [19]. The meaning that can be gleaned from this agreement is as the early stage of sociocultural life of the Minangkabau people and as the culmination of ideological consensus deliberations that are very important in the intellectual history of indigenous peoples and scholars in Minangkabau.

The third period (1830-1838) was marked by the high intensity of war on both sides, after the Diponegoro war in Central Java was won by the Netherlands with his strategy of deception. Then the Netherlands set the tactics of war by exerting all his strength in minangkabau, then the war of Padri flared the third period. Resistance from the Padri grew so great against the Netherlands that the Netherlands in 1833, asked Tuanku Imam Bonjol to make peace with the Netherlands known as the Long Plaque treaty (Declaration Van Den Bosch) and the Leaders of Padri accepted the peace effort on security grounds. The content of the agreement is that the Netherlands does not interfere in the affairs of local indigenous institutions, and does not impose a direct tax system on the Minangkabau people [20].

However, the contents of the agreement could not last long, because the Minangkabau people were required to pay market taxes and taxes pitting chickens and rodi work for the benefit of the Netherlands. In addition, the issuance of the Long Plaque agreement as a Netherlands strategy to control the Minangkabau mainland as the center of power of the Padri, namely the Bonjol area and surrounding areas [21]. On that basis came the awareness of the Indigenous people and the Padri that in fact they were only used by the Netherlands, so there was a sense of nationalism on the part of the Indigenous people and the Padri. The awareness of nationalism born from indigenous peoples and Padri became the trigger for the creation of an understanding that the Minangkabau region should not be controlled by the invaders. This was the beginning of a total war of the entire Minangkabau war against the Netherlands. This is the reason why the war or civil conflict in Minangkabau between the Indigenous people and the Padri turned into a force on the basis of nationalism against the Netherlands.

Finally with the great power and tactics of sheep fighting (devide et impera) of the Netherlands, the territory of the Padri only lived bonjol territory, after being besieged for two years finally fell to the Netherlands. On October 25, 1837 Tuanku Imam Bonjol was arrested and then exiled to Cianjur, West Java. Then on January 19, 1839 was exiled to Ambon, then in 
1841 transferred to Manado until his death on November 6, 1864 [22].

\section{Padri War Strategy}

The success or not of a war is largely determined by various factors, one of which is the use of war strategies, namely as a science and art about the implementation of troop maneuvers and the use of weapons tools to win battles. The use of the right strategy can change the course of the battle can even win in a war. Clausewitz (1976) says that, no one starts a war or rather, there is no one sense to do it without first being clear in his mind what he wants to achieve with that war and how he does it [23]. So it can be said that war requires a rational strategy in order to be successful in achieving victory.

Likewise with the Padri war, after experiencing defeat to the Netherlands, the Padri also devised a strategy in order to defeat the Netherlands. Guerrilla warfare strategies implemented by the Padri in Lintau area were able to repelled raaff attacks in Tanjung Alam and Luhak Agam and Baso. The Padri were able to make the Netherlands Captain named Goffinet seriously injured until finally died. Guerrilla warfare strategy designed by the Padri reaped success, so it succeeded in pressing the Netherlands continuously and eventually retreated back to Batusangkar. The alliance between the Netherlands and the Indigenous people did not get much luck, because in April 1823, the Netherlands increased strength and the Raaf attacked the Lintau area again, however, the defense of the padri was too persistent for the Netherlands.

Padri's war strategy was to use universal war tactics supported by all the resources and forces in the Minangkabau, united into one force against the Netherlands. The power of the Minangkabau people arises on the basis of awareness and belief in its own power driven by primordial spirit and strong tribalism [24]. It can be said that the Movement of Resistance of the Minangkabau community against the Netherlands as a form of the rise of the national spirit of the people in Minangkabau. For 35 years the Netherlands fought against Padri's forces, then Minangkabau could be controlled by the Netherlands, after Tuanku Imam Bonjol as padri warlord was captured for Netherlands ruse.

The agreement of the Indigenous and Padri to unite into one force against the Netherlands, angered the Netherlands and accused the Sultan of Tangkal Alam Bagagar (Raja Pagaruyung) of treason, finally arrested and banished to Batavia. After the exile of Sultan Alam Bagagar, the Netherlands also made a treaty named Plakat Panjang. This agreement states that if the Netherlands have no intention to take control of minangkabau but only to trade. Indigenous people do not need to pay taxes anymore and remain in the auspices of the leader of the ruler.

Unity in the form of forces built together by the Indigenous people and the Padri united against the Netherlands is a concept of total war that has been rooted in Minangkabau culture. One of the cultures that has been hereditary from the ancestors was the attitude of gotong royong, helping each other in any case involving all the power of the Minangkabau people. This attitude of unity is already known by the Minangkabau people mentioned in the Minangkabau Customary proverb, namely the badunsanak dunsanak broken custom, the bakampuang kampuang fault custom, the nagari broken banagari custom, the babangso bangso broken custom (adat badunsanak dunsanak patahankan, adat bakampuang kampuang patahankan, adat banagari nagari patahankan, adat babangso bangso patahankan) [25]. This means that when there is a conflict, and the Minangkabau people are forced to choose, it has become a principle that the Minangkabau community will side with the family, the region and the nation that experience weakness.

The concept of total war is what underlies the struggle of the Indonesian nation in fighting the invaders who are persimmon, set into the country's defense system and included in national regulations. Padri's war strategy that began from the civil war turned united against the Netherlands, of course this is very interesting and can be a recommendation for the present and the future in making formulations of the concept of state defense.

\section{CONCLUSION}

Padri War is a civil war that has occurred in Minangkabau, precisely in the area of Pagaruyung Kingdom in tanah Datar regency of West Sumatra. The historical background of the Padri War dates back to religious and customary issues, before Netherlands colonists intervened. This dispute between fellow Minangkabau people took place in the early 17th century, precisely from 1803 to 1838 . There are several groups involved, namely the Padri, the indigenous people, and the Netherlands who then apply cunning tactics to divide the Minangkabau people.

The last period was in 1830-1837 which was a war between the Coalition of Indigenous peoples and padri against the Netherlands. This war became a place of resistance of the Minangkabau people against Netherlandsinvaders led by several prominent figures known as The Nan Salapan Tiger. Guerrilla warfare strategy supported by the full force of indigenous people and Padri in the war overwhelmed the Netherlands forces, resulting in many casualties. The length of padri's war against Netherlands forces, because the Indigenous people and the Padri and their leaders are united with the people and use the values of local wisdom, so that the chosen strategy can fight against the Netherlands for a long time.After 35 years of Padri troops fighting against the Netherlands, then Minangkabau can be controlled by the Netherlands. The defeat of the Padri due to the capture of Tuanku Imam Bonjol as padri warlord and Netherlands ruse and limited weapons owned. Then on January 19, 1839 Tuanku Imam Bonjol was banished to Ambon, then in 1841 transferred to Manado until his death on November 6, 1864. 


\section{BIBLIOGRAPH}

[1] Weigert and W. Hans., (1957). Principles of Political Geography, New York: Appleton-Century-Crofts

[2] Sartono Kartodirdjo., (1993). Introduction to the History of a New Indonesia: The History of the National Movement "From Colonialism to Nationalism". Jakarta, Publisher: Gramedia Pustaka Utama

[3] Directorate General of Culture., (1978). History of National Awakening of West Sumatra Region

[4] Saifullah, et al., (2017). The Historical Cultural Link of Minangkabau and The State of Nine. West Sumatra: Indonesian Institute of Arts Padang Panjang

[5] Hendriks., (1881). Oorlogvoeren op Sumatra, Indische Militair Tijdschrif

[6] Sugiono., (2015). Qualitative quantitative research methods and R\&D, Bandung: CV Alfabeta

[7] Azyumardi Azra., (2004). The Origins of Islamic Reformism in Southeast Asia: Networksof Malay-Indonesian and Middle Eastern Ulama in the Seventeenth and Eighteenth Centuries

[8] Marwati Djoened Poesponegoro Nugroho Notosusanto., (1992). National History of Indonesia. Jakarta: Library Hall

[9] Zulkifli Ampera Salim., (2005). Minangkabau in the Scattered Historical Record. PadangIndonesian cultural image.

[10] M.D. Mansoer, et al., (1970). Sedjarah Minangkabau, Library Hall. Jakarta:Bhtratara

[11] Sjafnir Aboe Naim., (2008). Tuanku Imam Bonjol: The Intellectual History of Islam in Minangkabau (1784-1832). Padang: Padang Publisher
[12] Poerwadarminta,W.J.S., (1990). General Dictionary Indonesian. Jakarta: PN. Library Hall

[13] Mhd Nur., et al, (2016).Sultan Alam Bagagar Syah Struggle Against Netherlands Invaders in Minangkabau In the 19th Century, Tabing Padang: West Sumatra

[14] Syafnir Abu Naim., (1993). Tuanku Imam Bonjol, Padang: Esa

[15] Cristene Dobbin., (1992). The Rise of Islam in the Changing Farmer Economy: Central Sumatra 1784-1847, Ter. Lilian D. Tedjasudhana, Jakarta: INIS

[16] Kahin, A., (2008). From Rebellion to Integration: West Sumatra and Indonesian Politics (1926-1998). Jakarta: Obor Indonesia Foundation

[17] Amran, Rusli., (1981). West Sumatra To Plakat Panjang, Jakarta: Sinar Harapan

[18] Azyumardi Azra., (2003). Surau Traditional Islamic Education in Transition and Modernization, Jakarta: Logos Wacana Ilmu

[19] Uun Lionar, et al., (2020). Long Plaque Until the Kamang War: Minangkabau People's Movement Against Netherlands Colonial Taxes, Journal of Studies, Research \& Development of Historical Education

[20] Ricklefs, M.C., (2008). History of Modern Indonesia (Tim Serambi, Translator). Jakarta: Serambi

[21] Perwita, Anak Agung Banyu., (2013). Introduction to strategic studies, Jakarta: Graha Ilmu

[22] Danil Mahmud Chaniago., (2020). NATIONALISM Roots and Growth in Minangkabau, Padang: UIN Imam Bonjol Padang

[23] Damsar, Indrayani., (2016). Minangkabau Socio-Cultural Construction over the Market, journal Anthropology: SocioCultural Issues 